\title{
Pyroglutamate-Amyloid- $\beta$ and Glutaminyl Cyclase Are Colocalized with Amyloid- $\beta$ in Secretory Vesicles and Undergo Activity-Dependent, Regulated Secretion
}

\author{
Holger Cynis $^{a} \quad$ Lydiane Funkelstein $^{b, c}$ Thomas Toneff ${ }^{b, c}$ Charles Mosier $^{b, c}$ \\ Michael Ziegler ${ }^{b}$ c Birgit Koch ${ }^{a}$ Hans-Ulrich Demuth ${ }^{a, d}$ Vivian Hook ${ }^{b, c}$

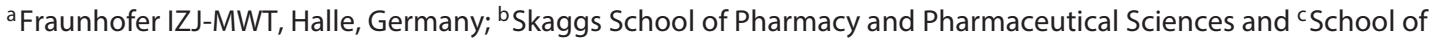

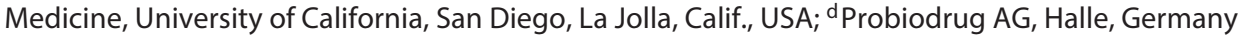

\section{Key Words}

Pyroglutamate · Glutaminyl cyclase $\cdot$ Amyloid $-\beta$ - Secretory vesicles

\begin{abstract}
Background and Aims: N-truncated pyroglutamate (pGlu)amyloid- $\beta[A \beta(3-40 / 42)]$ peptides are key components that promote $A \beta$ peptide accumulation, leading to neurodegeneration and memory loss in Alzheimer's disease. Because $A \beta$ deposition in the brain occurs in an activity-dependent manner, it is important to define the subcellular organelle for pGlu-A $\beta(3-40 / 42)$ production by glutaminyl cyclase (QC) and their colocalization with full-length $A \beta(1-40 / 42)$ peptides for activity-dependent, regulated secretion. Therefore, the objective of this study was to investigate the hypothesis that pGlu-A $\beta$ and $Q C$ are colocalized with $A \beta$ in dense-core secretory vesicles (DCSV) for activity-dependent secretion with neurotransmitters. Methods: Purified DCSV were assessed for pGlu-A $\beta(3-40 / 42), A \beta(1-40 / 42), Q C$, and neurotransmitter secretion. Neuron-like chromaffin cells were analyzed for cosecretion of pGlu-A $\beta, Q C, A \beta$, and neuropeptides. The cells were treated with a $Q C$ inhibitor, and $p G l u-A \beta$ production was measured. Human neuroblastoma cells were also exam-
\end{abstract}

ined for pGlu-A $\beta$ and $Q C$ secretion. Results: Isolated DCSV contain pGlu-A $\beta(3-40 / 42), Q C$, and $A \beta(1-40 / 42)$ with neuropeptide and catecholamine neurotransmitters. Cellular pGlu$A \beta$ and $Q C$ undergo activity-dependent cosecretion with $A \beta$ and enkephalin and galanin neurotransmitters. The QC inhibitor decreased the level of secreted $p G l u-A \beta$. The human neuroblastoma cells displayed regulated secretion of pGlu$A \beta$ that was colocalized with $Q C$. Conclusions: $p G l u-A \beta$ and $Q C$ are present with $A \beta$ in DCSV and undergo activity-dependent, regulated cosecretion with neurotransmitters.

(c) 2014 S. Karger AG, Base

\section{Introduction}

Accumulation of neurotoxic $\beta$-amyloid $(A \beta)$ peptides in the brain represents a key factor in the development of memory deficits in Alzheimer's disease (AD) [1-4]. A $\beta$ peptides of multiple forms are present in AD brains. Notably, affected AD brains contain the $\mathrm{N}$-terminally trun-

Holger Cynis and Lydiane Funkelstein contributed equally to this study. 
cated pyroglutamate (pGlu) forms of $A \beta(3-40 / 42)$ (pGlu$A \beta)$ as a major portion of the total $A \beta$ peptides, which includes the known full-length $A \beta(1-40 / 42)$ peptides [57]. The accumulation of pGlu-A $\beta(3-40 / 42)$ in the brain occurs before that of the $A \beta(1-40 / 42)$ peptides [5]. Significantly, pGlu-A $\beta$ facilitates the seeding of $A \beta$ peptides into neurotoxic oligomers [8] that are thought to participate in the development of memory deficits in $\mathrm{AD}$ [9]. Increasing the brain levels of pGlu- $A \beta(3-42)$ resulted in aggravated memory deficits and amyloid plaque accumulation in the 5XFAD mouse model of $\mathrm{AD}$ [10], illustrating the key role of $\mathrm{N}$-truncated pGlu-modified forms of $\mathrm{A} \beta$ in $\mathrm{AD}$.

The pGlu-A $\beta(3-40 / 42)$ peptides start with $N$-terminal glutamate, the third amino-terminal residue of $A \beta(1-$ $40 / 42)$. Notably, this residue is converted to pGlu by the enzyme glutaminyl cyclase (QC) $[8,11,12]$. QC is elevated in AD brains [5-7]. Moreover, inhibition of QC [13, 14] results in decreased brain pGlu-A $\beta$ levels, and QC gene knockout results in decreased brain pGlu-A $\beta$ levels with improved behavioral deficits in 5XFAD mice [12]. These findings indicate that QC is involved in the development of $\mathrm{AD}$ via formation of pGlu-A $\beta$.

$A \beta$ peptides have been demonstrated to be released from brain neurons in an electrical activity-dependent manner [15-19]. Neural activity modulates the formation and secretion of $A \beta[20,21]$. Recent evidence indicates that endogenous neuronal activity regulates regional brain vulnerability to $A \beta$ deposition [22]. Significantly, neuronal activity is fundamental for the regulated secretion of neurotransmitters $[23,24]$. These features of $A \beta$ peptides raise the question of whether pGlu-A $\beta$ and its biosynthetic enzyme $\mathrm{QC}$ are cosecreted with $\mathrm{A} \beta$ and neurotransmitters in a regulated, activity-dependent manner. Therefore, this study investigated the hypothesis that cosecretion of truncated pGlu-A $\beta$ and full-length $A \beta$ occurs with neurotransmitters stored and released from secretory vesicles, resulting in extracellular $A \beta$ peptide forms. These studies utilized neuronal chromaffin cells that display activity-dependent secretion of neurotransmitters and also produce $A \beta[17,19]$, as well as human IMR32 neuroblastoma cells.

Our results show that secretory vesicles of the densecore secretory vesicle (DCSV) type contain pGlu-A $\beta$ with $\mathrm{QC}$ and $\mathrm{A} \beta$ combined with catecholamine and peptide neurotransmitters. Cellular pGlu-A $\beta$ and QC undergo cosecretion from the regulated secretory pathway of neuron-like chromaffin cells stimulated by nicotine or $\mathrm{KCl}$ depolarization. pGlu-A $\beta$ also undergoes regulated cosecretion with $A \beta$ and the peptide neurotransmitters me- thionine Met-enkephalin and galanin peptide. Treatment of cells with a QC inhibitor resulted in decreased levels of pGlu-A $\beta$ released from the regulated secretory pathway. Furthermore, human neuroblastoma cells displayed regulated cosecretion of pGlu-A $\beta(3-40)$ with $A \beta(1-40 / 42)$ combined with colocalization of $\mathrm{pGlu}-\mathrm{A} \beta$ and $\mathrm{QC}$. These findings support the hypothesis that pGlu-A $\beta$ and $Q C$ undergo cosecretion with $A \beta$ and peptide neurotransmitters from the activity-dependent, regulated secretory pathway.

\section{Experimental Procedures}

Content of $p G l u-A \beta, Q C, A \beta$ Peptides, and Neurotransmitters in DCSV

Secretory vesicles were purified from fresh bovine adrenal medulla to evaluate the content of $\mathrm{QC}$, pGlu- $\mathrm{A} \beta, \mathrm{A} \beta$ peptides, Metenkephalin and galanin peptide neurotransmitters, and the catecholamine neurotransmitters dopamine, norepinephrine, and epinephrine. These DCSV, also known as chromaffin granules, were isolated by differential sucrose density gradient centrifugation, as previously described [25-29]. The density gradient isolation procedure has been established to yield secretory vesicles of high purity based on the assessment of organelle markers and on electron microscopy [25-29]. The procedure results in purified secretory vesicles that lack biochemical markers for other subcellular organelles of lysosomes (acid phosphatase marker), cytoplasm (lactate dehydrogenase marker), mitochondria (fumarase and glutamate dehydrogenase markers), and the endoplasmic reticulum (glucose-6-phosphatase marker). Enzyme markers in the purified secretory vesicle preparation represent less than $1 \%$ of the total amount of homogenate markers. Furthermore, electron microscopy and enzyme markers have confirmed the integrity and purity of isolated DCSV [25-29].

The presence of QC in isolated DCSV was assessed by monitoring QC enzymatic activity as previously described [30-32]. QC in chromaffin granules was subjected to immunoprecipitation with anti-QC - conducted as previously described [33] - followed by Western blotting with anti-QC sera (rabbit CPC1301, from Probiodrug), using Western blot procedures as described [25, 33-35].

For the measurement of $A \beta$ peptides and neurotransmitters, purified secretory vesicles were lysed by freeze-thawing in buffer (50 mM Na acetate, $50 \mathrm{~mm} \mathrm{NaCl}, 1 \mathrm{~mm}$ EDTA) containing a cocktail of protease inhibitors (pepstatin A, leupeptin, chymostatin, and E64c at $10 \mu \mathrm{M}$ each, and PMSF at $500 \mu \mathrm{M}$ ). An acid extract $(0.1 \mathrm{~N}$ acetic acid) was prepared from the lysed secretory vesicles (as described previously $[25,26,34,35]$ ) for the measurement of pGlu- $A \beta(3-40)$, pGlu-A $\beta(3-42), A \beta(1-40), A \beta(1-42)$, Met-enkephalin, and galanin, and of the catecholamines dopamine, norepinephrine, and epinephrine. DCSV samples were subjected to ELISA measurements of pGlu-A $\beta(3-40)$ (No. 27418; IBL International, Toronto, Ont., Canada), pGlu-A $\beta(3-42)$ (No. 27716; IBL), $A \beta(1-40)$ (No. 27718; IBL), and $A \beta(1-42)$ (No. 27712; IBL), and RIA for Met-enkephalin and galanin (the RIAs were conducted as previously reported $[28,33,35])$. The well-established ELISA kits have been characterized to demonstrate their specificities for the 
particular peptides (by the manufacturer IBL). The ELISAs for $A \beta(1-40)$ and $A \beta(1-42)$ do not cross-react with each other, nor with the pGlu-A $\beta$ peptides; the ELISA for $\mathrm{pGlu}-\mathrm{A} \beta(3-40)$ does not detect pGlu-A $\beta(3-42)$ or $A \beta(1-40 / 42)$, and the ELISA for pGlu$A \beta(3-42)$ specifically detects this N-truncated peptide rather than pGlu-A $\beta(3-40)$ and does not detect $A \beta(1-40 / 42)$. QC activity was measured in the media, as previously described [30-32], using $\mathrm{H}-\mathrm{Gln}-\beta \mathrm{NA}$ as the substrate in a fluorometric assay. Dopamine, norepinephrine, and epinephrine catecholamines were measured by radioenzymatic assays, as previously described $[36,37]$. The protein content of the purified DCSV was measured by the BioRad DC Protein Assay (Lowry) kit (Bio-Rad, Hercules, Calif., USA). The contents of $A \beta$ peptides and neurotransmitters were expressed as picograms per milligram protein.

\section{Neuron-Like Chromaffin Cells in Primary Culture}

Neuron-like chromaffin cells in primary culture were obtained from the adrenal medulla of the sympathetic nervous system. In our study, they were prepared from fresh adrenal medulla tissue (bovine), as previously described $[25,35,38]$. Briefly, chromaffin cells were dissected from fresh adrenal glands, dissociated in a collagenase/DNase solution at $37^{\circ} \mathrm{C}$, filtered, and centrifuged. The cells were plated onto fibronectin-coated dishes (EMD Chemicals, Gibbstown, N.J., USA) in medium containing DMEM (Cellgro, Manassas, Va., USA), 10\% FBS (Invitrogen, Carlsbad, Calif., USA), and penicillin/streptomycin. The cells were maintained at $37^{\circ} \mathrm{C}$ and $6 \% \mathrm{CO}_{2}$.

Regulated Secretion of $p G l u-A \beta, Q C, A \beta$, and Peptide

Neurotransmitters from Chromaffin Cells

After 6 days in culture, the chromaffin cells were subjected to $\mathrm{KCl}$ depolarization or treatment with nicotine to stimulate regulated, activity-dependent secretion. They were incubated in standard release medium (as described by Bark et al. [28]) with 0.25 $\mu \mathrm{g} / \mathrm{ml} \mathrm{BSA}$ for $90 \mathrm{~min}$ at $37^{\circ} \mathrm{C}$, followed by removal of the medium, which represents basal secretion. Then they were stimulated for 90 $\min \left(\right.$ at $\left.37^{\circ} \mathrm{C}\right)$ in standard release medium containing $\mathrm{KCl}(50 \mathrm{mM})$ or nicotine $(10 \mu \mathrm{M})$, followed by collection of the medium, which represents regulated secretion. The secretion medium was collected with addition of a cocktail of protease inhibitors (1 mM EDTA, $500 \mu \mathrm{M}$ AEBSF, and $10 \mu \mathrm{M}$ each of E64c, leupeptin, pepstatin A, and chymostatin). Then it was concentrated by ultrafiltration through a 2-kDa cut-off membrane (Vivaspin $22 \mathrm{~K}$ MWCO Hydrosart; Sartorius, Göttingen, Germany), which retains $A \beta$. The concentrated sample was subjected to measurements of pGlu$\mathrm{A} \beta(3-40)$, pGlu-A $\beta(3-42), A \beta(1-40), A \beta(1-42)$, Met-enkephalin, and galanin, as described above for DCSV. QC activity was measured in the medium, as previously described [30, 31], using $\mathrm{H}-\mathrm{Gln}-\beta \mathrm{NA}$ as the substrate in a fluorometric assay.

\section{Inhibition of Endogenous QC in Chromaffin Cells and Levels of} Secreted $p G l u-A \beta(3-40)$

The chromaffin cells were incubated with the QC inhibitor PQ529 (Probiodrug AG, Halle, Germany) at $50 \mu \mathrm{M}$ for $18 \mathrm{~h}$. They were then subjected to regulated secretion induced by treating cells with $\mathrm{KCl}(50 \mathrm{~mm})$ for $90 \mathrm{~min}$. Control incubation without $\mathrm{KCl}$ was also included. The cell culture medium was then collected for the measurement of pGlu-A $\beta(3-40)$ by ELISA (as described above).

pGlu-A $\beta$ and QC Colocalization with $\mathrm{A} \beta$ in Secretory Vesicles
Cellular Immunofluorescence Localization of $p$ Glu- $A \beta$ and $Q C$ with Met-Enkephalin Neurotransmitter Present in Secretory Vesicles

Immunofluorescence microscopy of the chromaffin cells was conducted to assess the subcellular localization of pGlu-A $\beta$ and QC with Met-enkephalin in the DCSV that undergo regulated secretion. The chromaffin cells were fixed for immunofluorescence deconvolution microscopy, conducted as previously described [33-35]. The primary antibodies used for immunocytochemistry were rabbit anti-QC 1301 (1:250; Probiodrug AG), mouse antiMet-enkephalin (1:100, Abcam No. 23503; Abcam, Cambridge, Mass., USA), mouse anti-pGlu-A $\beta$ (1:50; Probiodrug AG) detecting the $\mathrm{N}$-terminus of both pGlu-A $\beta(3-40)$ and pGlu-A $\beta(3-42)$, rabbit anti-Met-enkephalin (1:50; Millipore, Billerica, Mass., USA), and mouse anti-amyloid precursor protein (APP) clone 6E10 (1:100; Covance, Princeton, N.J., USA). The primary antibodies were detected with the secondary antibodies anti-rabbit IgG-Alexa Fluor 594 (goat, 1:200 dilution, red fluorescence; Molecular Probes, Eugene, Oreg., USA) and anti-mouse IgG-Alexa Fluor 488 (goat, 1:200 dilution, green fluorescence; Molecular Probes). The immunofluorescent images were analyzed by DeltaVision Spectris Image Deconvolution Systems on an Olympus IX70 epifluorescence microscope using the software softWoRx Explorer by Applied Precision (GE Healthcare Company, Issaquah, Wash., USA), as previously described $[33,39]$. As a control procedure, immunostaining with only secondary antibody was performed, and the controls obtained demonstrated a lack of immunofluorescence, indicating the specificity of the primary immunoreactivity observed.

\section{Human IMR32 Neuroblastoma Cells and Regulated Secretion} of $p$ Glu- $A \beta$ with $A \beta$ Peptides

Human IMR32 neuroblastoma cells were obtained from ATCC (American Type Culture Collection, Crystal City, Va., USA) and cultured according to the manufacturer's instructions. Activitydependent secretion was achieved by stimulating secretion in the medium by incubation with $\mathrm{KCl}(50 \mathrm{~mm})$ for $90 \mathrm{~min}$. Control secretion for $90 \mathrm{~min}$ without $\mathrm{KCl}$ was included. The secretion media were collected, concentrated, and subjected to measurements of pGlu-A $\beta(3-40), A \beta(1-40)$, and $A \beta(1-42)$ (ELISA kits from IBL). Cellular localization of pGlu-A $\beta$ and $Q C$ was conducted by immunofluorescence confocal microscopy, as described above for chromaffin cells.

\section{Statistical Analysis of Data}

The secretion of $A \beta$ peptides and neurotransmitters was conducted in triplicate in each experiment, and the experiments were repeated 3 times. Data were considered statistically significant at $\mathrm{p}<0.05$ by Student's $\mathrm{t}$ test.

\section{Results}

\section{Secretory Vesicles Contain $p G l u-A \beta$ and $Q C$ with $A \beta$ and Neurotransmitters}

Several studies in the field have demonstrated that $A \beta$ undergoes activity-dependent, regulated secretion from neurons [15-18], implicating release from secretory ves- 


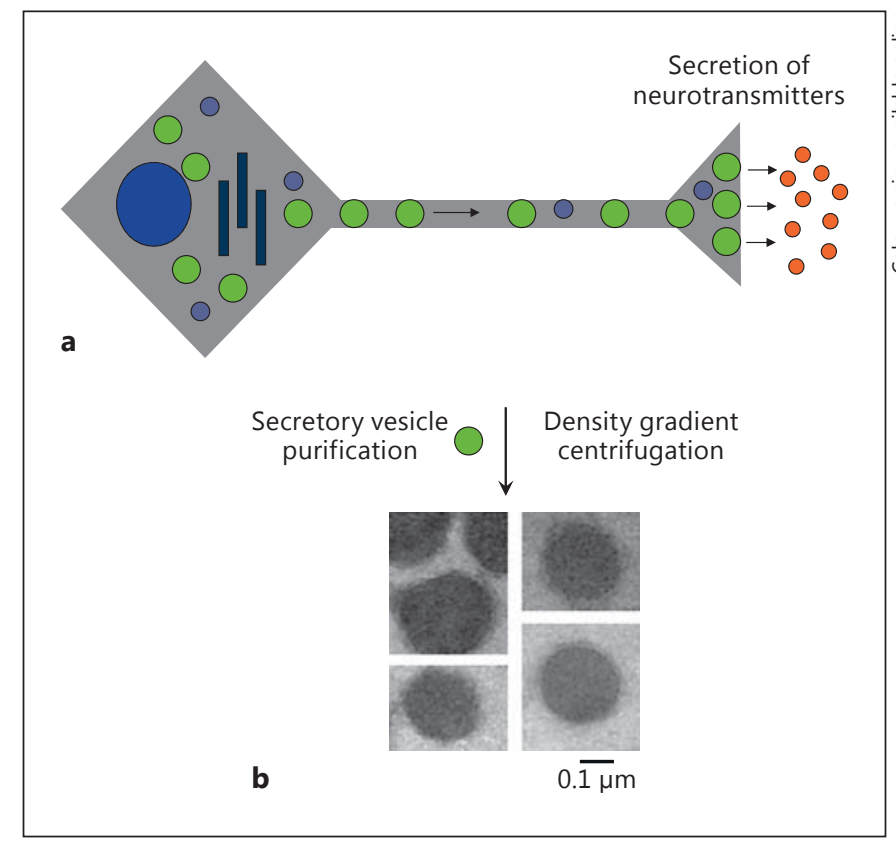

Fig. 1. a Neuronal secretion of neurotransmitters. Secretory vesicles of neurons provide synthesis, storage, and regulated secretion of neuropeptides, catecholamines, and bioactive neurotransmitter molecules that are critical for cell-cell communication in the nervous system. b DCSV observed by electron microscopy. Secretory vesicles of the DCSV type were isolated from chromaffin cells of bovine adrenal medulla tissue by differential sucrose gradient centrifugation, which results in a highly purified preparation of homogeneous DCSV $[25,28,29]$. The integrity of the purified DCSV is illustrated here.

Table 1. A $\beta$ peptides and neurotransmitters in purified DCSV

Content, pg/mg protein

$\begin{array}{cc}\text { A } \beta \text { peptides } & \\ \text { pGlu-A } \beta(3-40) & 0.022 \pm 0.004 \\ \text { pGlu-A } \beta(3-42) & 0.070 \pm 0.009 \\ \text { A } \beta(1-40) & 0.220 \pm 0.010 \\ \text { A } \beta(1-42) & 0.085 \pm 0.004 \\ \text { Peptide neurotransmitters } & 215,000 \pm 14.4 \\ \text { Met-enkephalin } & 408 \pm 0.015 \\ \text { Galanin } & \\ \text { Catecholamine neurotransmitters } & 1,150 \pm 0.13 \\ \text { Dopamine } & 4,560 \pm 0.34 \\ \text { Norepinephrine } & 6,490 \pm 1.02 \\ \text { Epinephrine } & \end{array}$

The concentrations of $\mathrm{A} \beta$ peptides and neurotransmitters in purified chromaffin DCSV were measured by assays as described in the Experimental Procedures section. icles that store and release neurotransmitters (fig. 1a). Therefore, our study investigated the hypothesis that pGlu-A $\beta$ and its biosynthetic enzyme QC may be present with $A \beta$ and neurotransmitters in secretory vesicles for extracellular release.

DCSV of neuron-like chromaffin cells store neurotransmitter contents for activity-dependent, regulated secretion; thus, they were isolated for this study. The DCSV were purified by sucrose density gradient centrifugation and the integrity of the isolated DCSV was illustrated by electron microscopy (fig. 1b). Previous reports have documented the high purity of these isolated DCSV by assessing enzyme markers for subcellular organelles $[25,28,29]$.

The isolated DCSV contained pGlu-A $\beta(3-40)$, pGlu$\mathrm{A} \beta(3-42), A \beta(1-40)$, and $A \beta(1-42)$, quantitated by ELISA assays (table 1 ). The concentrations of pGlu-A $\beta(3-40)$ and pGlu-A $\beta(3-42$ ) (at approx. 0.022 and $0.070 \mathrm{pg} / \mathrm{mg}$ protein) represented 10 and $82 \%$ of the concentrations of $A \beta(1-40)$ and $A \beta(1-42)$, respectively. Moreover, the DCSV contained enkephalin and galanin peptide neurotransmitters, as well as the catecholamines dopamine, norepinephrine, and epinephrine (table 1). These data show that the DCSV contained pGlu-A $\beta$ and $A \beta$ peptides with peptide and catecholamine neurotransmitters.

The presence of QC activity in the isolated DCSV was demonstrated by an activity assay using $\mathrm{H}-\mathrm{Gln}-\beta \mathrm{NA}$ as substrate. The time-dependent formation of the QC product is illustrated in figure $2 \mathrm{a}$. Heat inactivation as well as omitting the auxiliary enzyme of the assay underlined the specificity of the test. Furthermore, QC protein is present in DCSV, as observed by anti-QC Western blots (fig. 2b).

\section{pGlu-A $\beta$ and QC Undergo Activity-Dependent,}

Regulated Secretion from Neuron-Like Chromaffin

Cells with $A \beta$ and Peptide Neurotransmitters

The activity-dependent secretion of neurotransmitters from neuron-like chromaffin cells was stimulated by $\mathrm{KCl}$ depolarization, which represents regulated secretion, and by nicotine, which activates the nicotinic cholinergic receptor [38, 40-42]. $\mathrm{KCl}$ depolarization and nicotine activation of the cholinergic receptor of chromaffin cells are utilized in the field to assess activity-dependent, regulated secretion [35, 40, 43-50]. $\mathrm{KCl}$ depolarization and nicotine stimulated the secretion of pGlu-A $\beta(3-40)$ (fig. 3a). Stimulated secretion (with $\mathrm{KCl}$ ) was severalfold greater than basal secretion (no $\mathrm{KCl}$ ). High $\mathrm{KCl}$ and nicotine stimulated the release of approximately $3-4 \%$ of the total cellular $\mathrm{A} \beta(3-40)$ (data not shown), but $\mathrm{KCl}$ and nicotine 


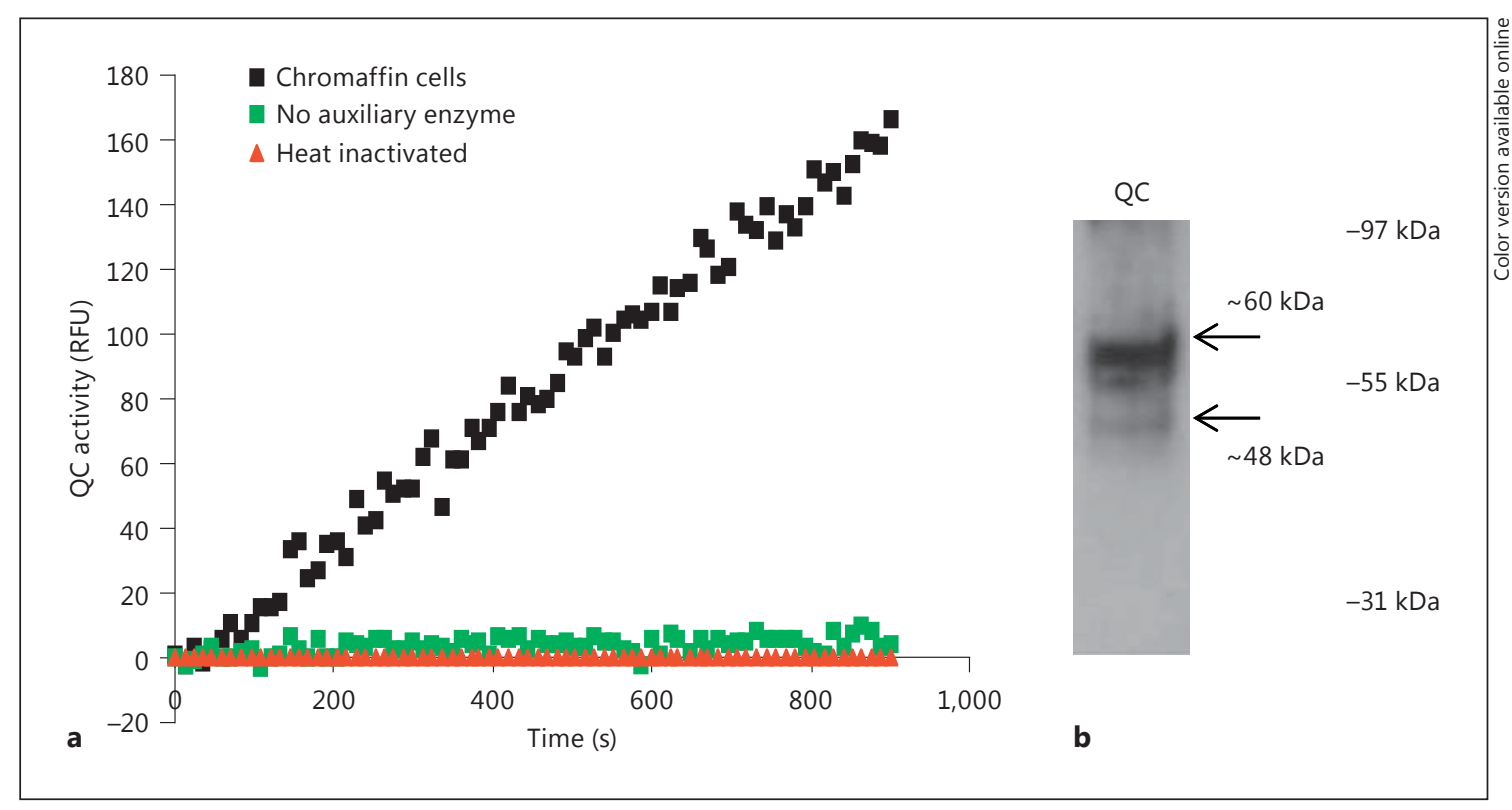

Fig. 2. a QC activity in DCSV. QC activity (black symbols) in purified DCSV of chromaffin cells (also known as chromaffin granules) was measured in time-course assays. The secretory vesicles showed no activity after heat inactivation (red symbols; colors in online version only) and after omission of the auxiliary enzyme of the test (green symbols). b QC protein in DCSV. Purified DCSV were subjected to anti-QC Western blots. Endogenous QC immunoreactive bands of approximately 60 and $48 \mathrm{kDa}$ were observed. The selectivity of anti-QC for detecting these immunoreactive bands was demonstrated by conducting a Western blot with only the secondary anti-rabbit serum (omitting the primary anti-QC serum), which resulted in the absence of immunoreactivity (unpublished data). It is noted that, on SDS-PAGE, endogenous bovine pituitary QC has been observed with an apparent molecular weight of approximately $40-45 \mathrm{kDa}$ [101], and recombinant nonglycosylated murine QC at a molecular weight of $37-40 \mathrm{kDa}$ [31]. Glycosylation of endogenous QC is known to modify its apparent molecular weight [102].
Fig. 3. Activity-dependent cosecretion of pGlu-A $\beta$ and QC from neuron-like chromaffin cells. * Statistically significant for comparison of stimulated cells (by $\mathrm{KCl}$ or nicotine) with unstimulated control cells ( $\mathrm{p}<0.05$, Student's $\mathrm{t}$ test). a Regulated secretion of pGlu-A $\beta$. This was induced by $\mathrm{KCl}$ depolarization and nicotine treatment of neuron-like chromaffin cells (90-min incubation time) with the inclusion of unstimulated controls. The secretion medium was collected for measurement of pGlu-A $\beta(3-40)$. b Regulated secretion of QC activity. The secretion media from the experiments of a were collected and measured for QC activity.

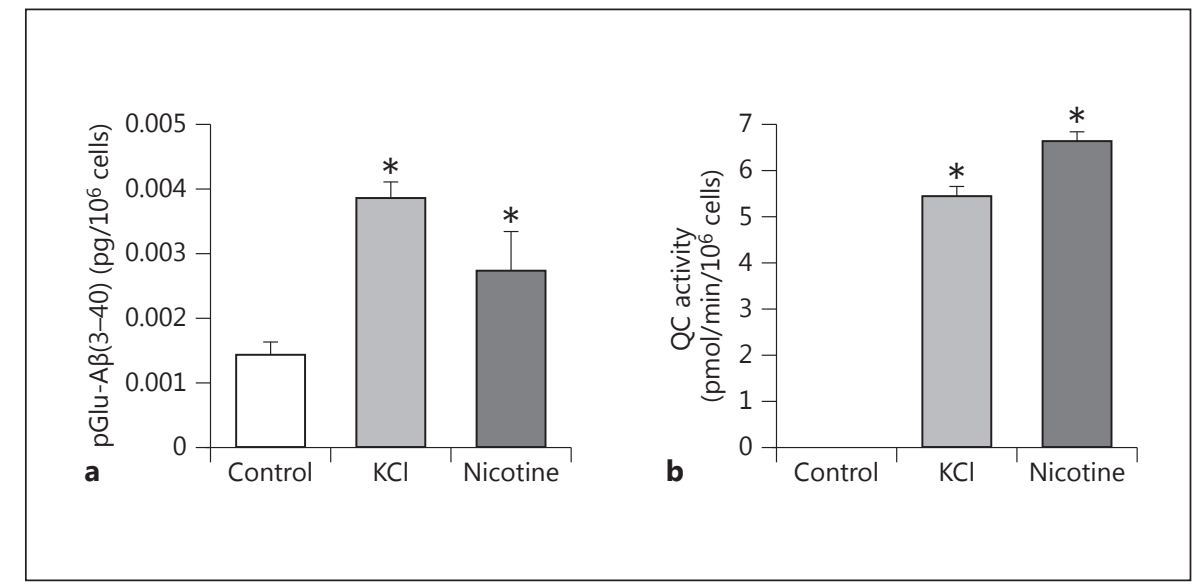

stimulated the predominate portion of secreted $A \beta(3-40)$ compared with the condition of basal constitutive secretion. Notably, QC, the biosynthetic enzyme for pGlu-A $\beta$, undergoes activity-dependent cosecretion with pGlu$\mathrm{A} \beta(3-40)$ (fig. 3b).

pGlu-A $\beta$ and QC Colocalization with $A \beta$ in Secretory Vesicles
Furthermore, $\mathrm{KCl}$ and nicotine stimulated the secretion of $A \beta(1-40)$ and $A \beta(1-42)$ (fig. 4). Because regulated, activity-dependent secretion is fundamental for the release of neurotransmitters, the peptide neurotransmitters Met-enkephalin and galanin were evaluated in these 
Fig.4. Activity-dependent, regulated secretion of $A \beta$ and peptide neurotransmitters. * Statistically significant for comparison of stimulated cells (by $\mathrm{KCl}$ or nicotine) with unstimulated control cells ( $\mathrm{p}<0.05$, Student's t test). $\mathbf{a}, \mathbf{b}$ Regulated secretion of $\mathrm{A} \beta(1-40)$ (a) and $\mathrm{A} \beta(1-42)$ (b) from chromaffin cells was stimulated by KCl depolarization and by nicotine, as conducted in figure 3. $A \beta(1-40)$ and $A \beta(1-42)$ were measured in the secretion media. c, d Regulated secretion of Met-enkephalin (c) and galanin peptide (d) neurotransmitters from chromaffin cells was stimulated by $\mathrm{KCl}$ depolarization and by nicotine, as conducted in figure 3, and the neuropeptides Met-enkephalin and galanin were measured in the secretion media.
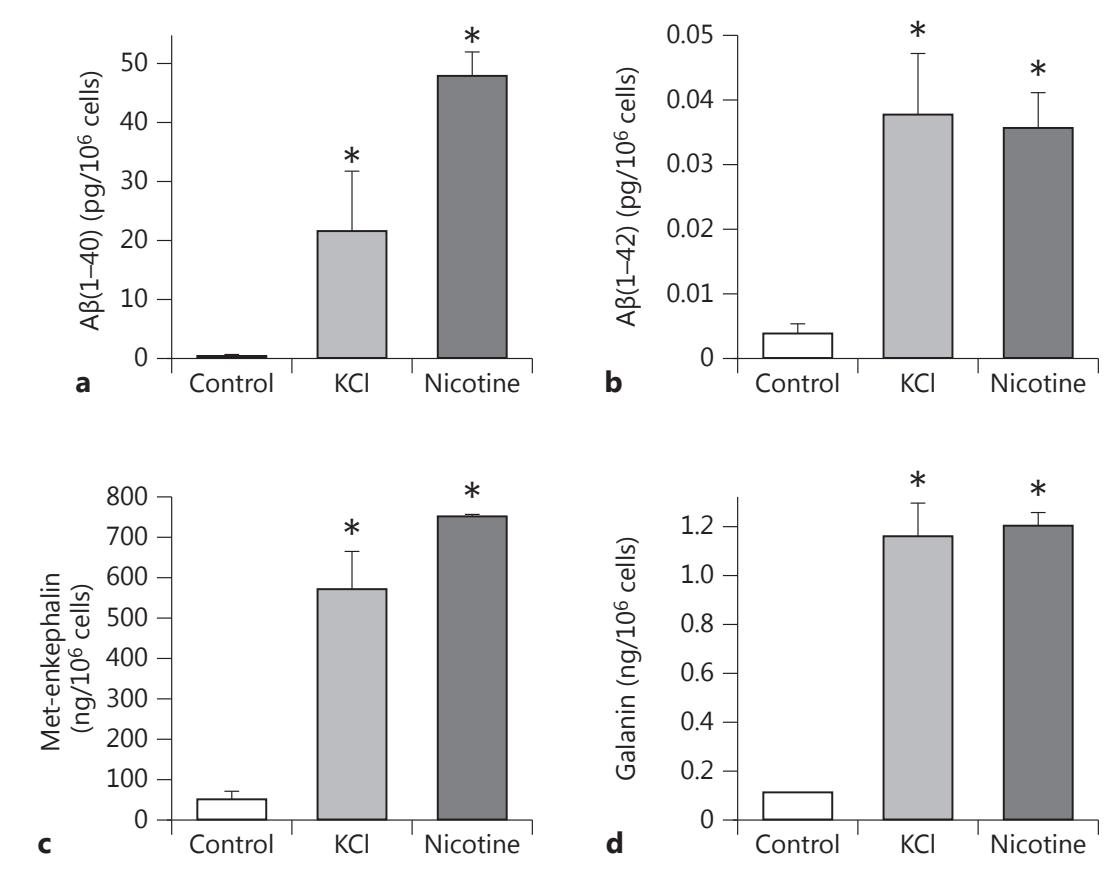

Fig. 5. Inhibitor of $Q C$ reduced the release of $p G l u-A \beta$ from the regulated secretory pathway. Chromaffin cells were either incubated with the QC inhibitor PQ529 for 18 h or not. Cells were then subjected to regulated secretion induced by $\mathrm{KCl}$ depolarization (for $90 \mathrm{~min}$ ), whereas control cells remained unstimulated. The secretion media were collected and measured for concentrations of pGlu-A $\beta(3-40)$. The data show that the inhibitor substantially reduced the amount of pGlu-A $\beta(3-40)$ released from the regulated secretory pathway, representing activity-dependent secretion. \# Statistically significant comparison of PQ529-treated with control cells (without PQ529) undergoing $\mathrm{KCl}$ depolarization-induced secretion of pGlu-A $\beta(3-40)(\mathrm{p}<0.05$, Student's t test). * Statistically significant comparison of $\mathrm{KCl}$ with control cells (without inhibitor treatment) with respect to secretion of pGlu-A $\beta(3-40)(p<0.05$, Student's t test).

experiments. Met-enkephalin and galanin were secreted in an activity-dependent manner, stimulated by $\mathrm{KCl}$ depolarization or nicotine (fig. 4). These data illustrate the cosecretion of pGlu-A $\beta(3-40)$ and QC with $A \beta(1-40 / 42)$ and the neurotransmitters Met-enkephalin and galanin.

\section{Inhibition of Endogenous QC Reduces $p G l u-A \beta$ in the Regulated Secretory Pathway}

The role of QC in the production of pGlu-A $\beta$ was evaluated with the QC inhibitor PQ529 [51]. Chromaffin cells

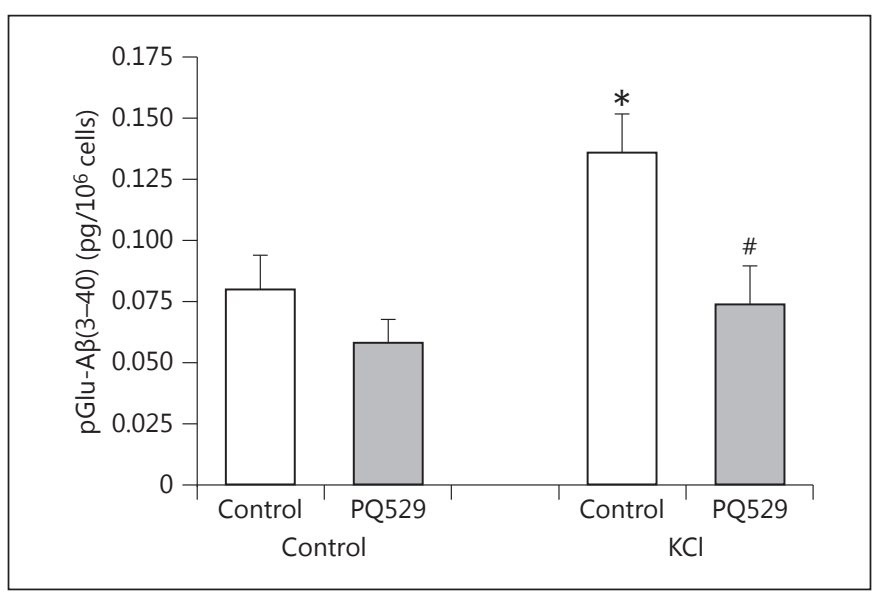

were treated with PQ529 $(50 \mu \mathrm{M})$ for $18 \mathrm{~h}$, and then subjected to regulated secretion stimulated by $\mathrm{KCl}$ depolarization. The results demonstrated that PQ529 significantly reduced the amount of pGlu-A $\beta(3-40)$ released via the regulated secretory pathway (fig. 5). Basal, constitutive levels of secreted pGlu-A $\beta(3-40)$ were not reduced by PQ529, although a modest, insignificant decrease was observed with PQ529. These findings support the role of QC in producing pGlu-A $\beta$ in DCSV via the regulated secretory pathway that provides activity-dependent secretion.
90

Neurodegener Dis 2014;14:85-97 DOI: $10.1159 / 000358430$
Cynis/Funkelstein/Toneff/Mosier/

Ziegler/Koch/Demuth/Hook 


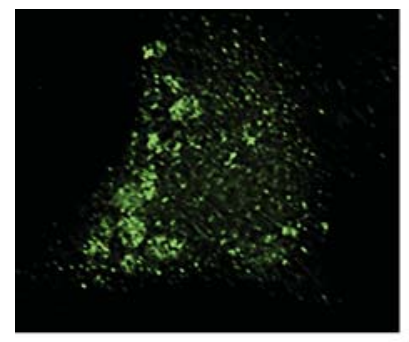

a

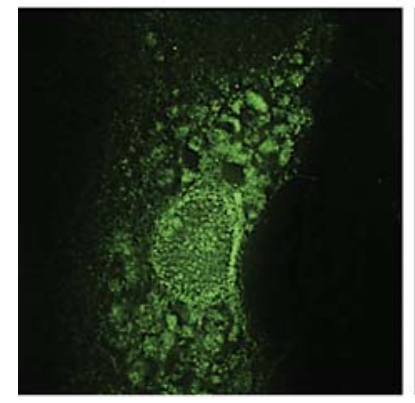

QC

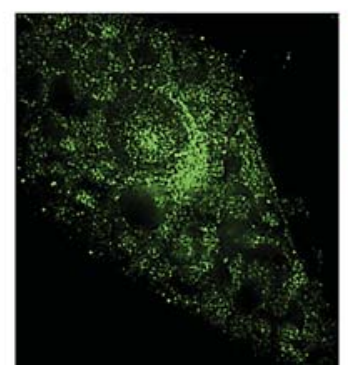

c $\quad$ QC

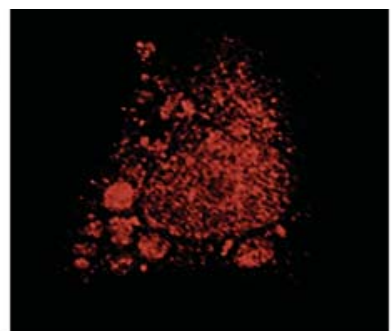

Enkephalin

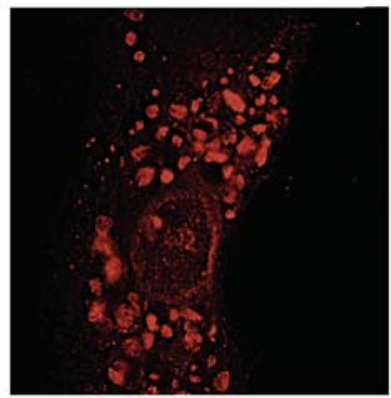

Enkephalin

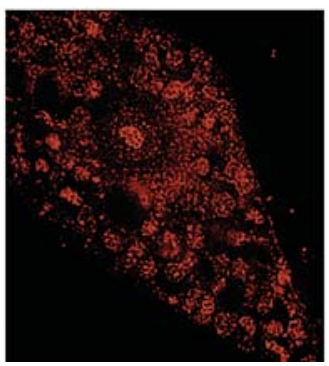

$6 \mathrm{E} 10$

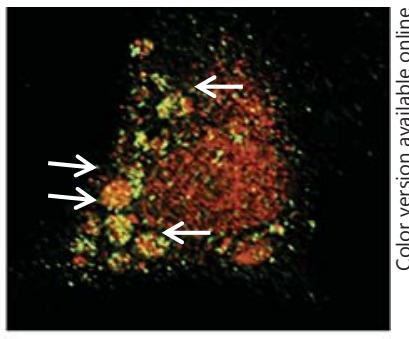

pGlu-Aß/enkephalin

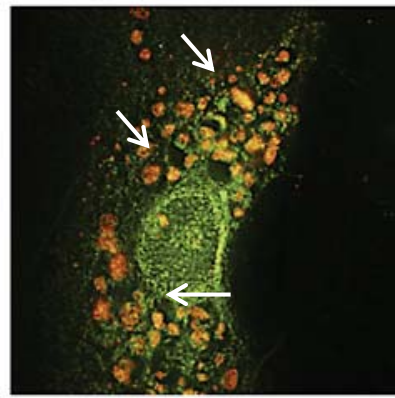

QC/enkephalin

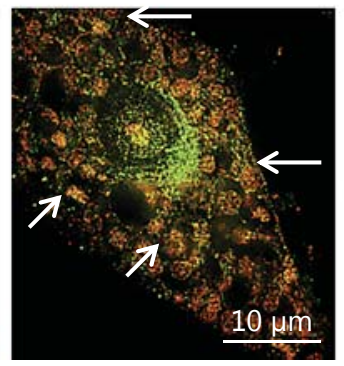

QC/6E10
Cellular Localization of $p G l u-A \beta$ and $Q C$ with

Enkephalin in Secretory Vesicles

Neurotransmitter and neurosecretory components that undergo regulated secretion are stored in secretory vesicles. Therefore, the colocalization of pGlu-A $\beta$ and QC with the Met-enkephalin neurotransmitter was demonstrated by immunofluorescence confocal microscopy (fig. 6). The data show the cellular colocalization of pGlu$\mathrm{A} \beta$ with Met-enkephalin in chromaffin cells (fig. 6a). The punctate pattern of subcellular pGlu-A $\beta$ localization coincides with that of Met-enkephalin which is present in secretory vesicles, shown by their merged yellow immunofluorescence (fig. 6a). Furthermore, QC is also colocalized with enkephalin (fig. 6b), indicating the presence of both QC and pGlu-A $\beta$ in enkephalin neurotransmitter-containing secretory vesicles. These data are consistent with the presence of pGlu-A $\beta$ and $\mathrm{QC}$ in secretory vesicles that contain neurotransmitters (table 1; fig. 2).

pGlu-A $\beta$ and QC Colocalization with $A \beta$ in Secretory Vesicles
The colocalization of QC with A $\beta$ - and APP-related forms was assessed by the $6 \mathrm{E} 10$ antibody, which detects $\mathrm{A} \beta$ - and APP-related immunoreactivity. The data show a punctate localization of QC and 6E10 immunoreactivity, showing colocalization (fig. $6 \mathrm{c}$ ). These results support the hypothesis on the combined presence of pGlu-A $\beta$ and QC with APP- and A $\beta$-related peptide forms in secretory vesicles.

\section{Human Neuroblastoma Cells Display}

Activity-Dependent, Regulated Secretion of $p G l u-A \beta$ with $A \beta$ Peptides

An evaluation in a human neuroblastoma cell line (IMR32) was conducted to assess the regulated secretion of pGlu-A $\beta$ in a human neuronal model. The secretion of pGlu-A $\beta(3-40)$ was stimulated by $\mathrm{KCl}$ and compared with basal control cells (no KCl; fig. 7a). In addition, regulated cosecretion of $A \beta(1-40)$ and $A \beta(1-42)$ was stimu- 

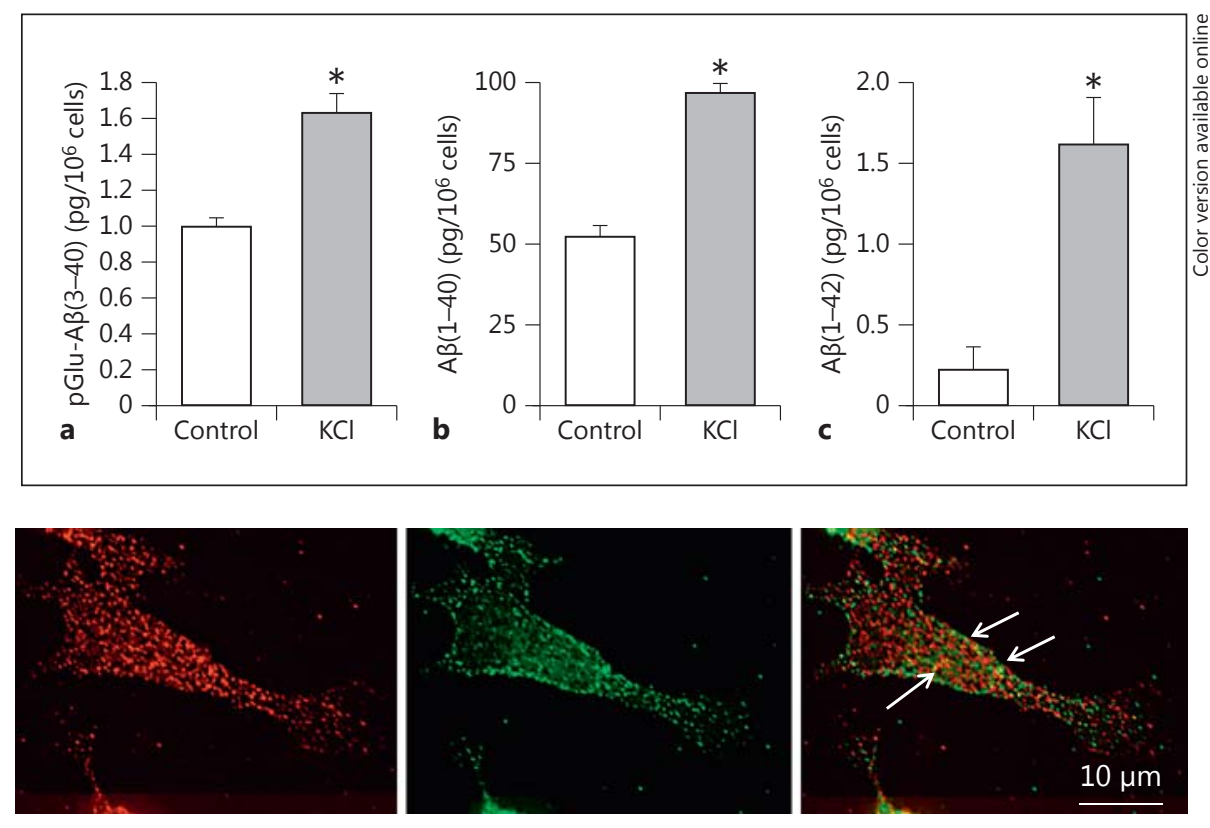

d

pGlu-A $\beta$

QC

pGlu-Aß/QC

Fig. 7. Activity-dependent cosecretion of pGlu-A $\beta$ with $A \beta$ peptides in IMR32 neuroblastoma cells. a pGlu-A $\beta(3-40)$ secretion stimulated by $\mathrm{KCl}$ depolarization. Human IMR32 neuroblastoma cells were subjected to secretion induced by $\mathrm{KCl}$ depolarization $(90$ $\mathrm{min})$, and pGlu-A $\beta(3-40)$ was measured in the secretion media by ELISA. b A $\beta(1-40)$ secretion induced by $\mathrm{KCl}$. A $\beta(1-40)$ was measured in the secretion media, as described above. c $A \beta(1-42)$ secretion induced by $\mathrm{KCl}$. $\mathrm{A} \beta(1-42)$ was measured in the secretion media, as described above. a-c * Statistically significant for $\mathrm{KCl}$

lated by $\mathrm{KCl}$ (fig. 7b, c). Immunofluorescence microscopy illustrated the colocalization of pGlu-A $\beta$ with QC (fig. 7d). pGlu-A $\beta$ and QC were each observed in discrete, punctate patterns of subcellular distribution. Merging of their images displayed their colocalization (shown by the yellow immunofluorescence). These data demonstrate the regulated cosecretion of $\mathrm{pGlu}-\mathrm{A} \beta$ with $\mathrm{A} \beta$ peptides, and the colocalization of pGlu-A $\beta$ with QC in human neuroblastoma.

\section{Discussion}

This study demonstrates an activity-dependent, regulated cosecretion of pGlu- $A \beta$ and $Q C$ with $A \beta$ and peptide neurotransmitters from secretory vesicles. The isolated secretory vesicles (DCSV type) used in our study contained pGlu-A $\beta, Q C$, full-length $A \beta$ peptides, as well as peptide and catecholamine neurotransmitters. The compared with control (unstimulated; $\mathrm{p}<0.05$, Student's t test). d Colocalization of pGlu-A $\beta$ (red; colors in online version only) with QC (green). The subcellular localizations in the human IMR32 neuroblastoma cells were assessed by immunofluorescence microscopy. Merged image: areas of colocalization of pGlu-A $\beta$ with QC (yellow, arrows). Controls that were not treated with the primary antisera but only with the secondary fluorescence-labelled antisera resulted in an absence of immunofluorescence signals for pGlu-A $\beta$ and QC. data show that release of DCSV contents results in the cosecretion of pGlu-A $\beta$ with $\mathrm{QC}, \mathrm{A} \beta$, and peptide neurotransmitters from the regulated secretory pathway of neuron-like chromaffin cells. Cellular immunofluorescence microscopy also illustrated the colocalization of pGlu-A $\beta$ with QC and enkephalin, and of QC with APPand $A \beta$-related immunoreactivity. Treatment of cells with a $Q C$ inhibitor resulted in reduced levels of pGlu-A $\beta$ released from the regulated secretory pathway, indicating the role of $\mathrm{QC}$ in the production of pGlu-A $\beta$. Furthermore, human neuroblastoma cells displayed regulated secretion of pGlu-A $\beta$ and $A \beta$, and pGlu-A $\beta$ was colocalized with QC. These data demonstrate that $\mathrm{pGlu}-\mathrm{A} \beta$ and $\mathrm{QC}$ undergo regulated cosecretion with $A \beta$ from neurotransmitter secretory vesicles to provide extracellular pGlu-A $\beta$ with $\mathrm{A} \beta$ that accumulates in $\mathrm{AD}$ brains.

The combined presence of pGlu-A $\beta$ and $Q C$ with $A \beta$ in neurotransmitter secretory vesicles raises the question of how $A \beta$ and $p G l u-A \beta$ are produced in this organelle. 


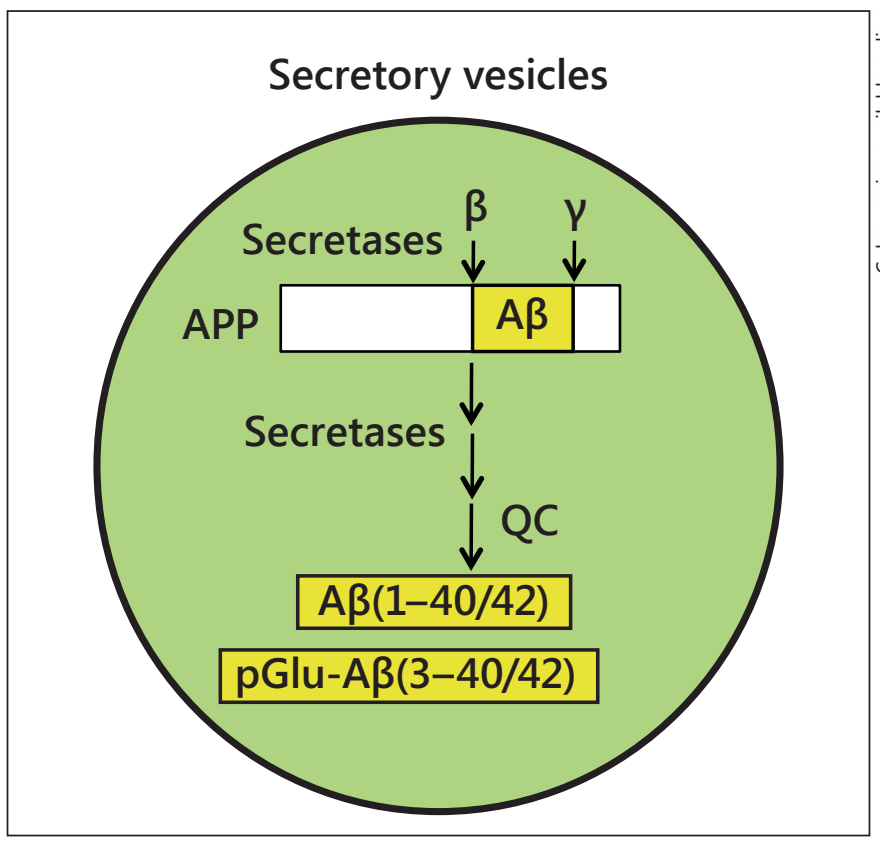

Fig. 8. $p$ Glu-A $\beta$ and $A \beta$ peptides with $Q C$ and the APP-processing machinery in secretory vesicles containing neurotransmitters. In this study, the secretory vesicles (DCSV type) isolated from model neuron-like chromaffin cells were demonstrated to contain pGlu$A \beta(3-40 / 42)$ and $Q C$ combined with $A \beta(1-40 / 42)$. Prior studies have indicated the presence of $\beta-, \gamma^{-}$, and $\alpha$-secretases in DCSV $[58,59,62]$. DCSV contain cathepsin $B$, which has been identified as a new alternative $\beta$-secretase [59-61], and the well-known $\beta$-secretase BACE1 [58, 62], an aspartyl protease [54-57]. The components of the $\gamma$-secretase complex are also present in DCSV [58], i.e. presenilins 1 and 2, nicastrin, Aph-1, and Pen-2, which together function as $\gamma$-secretase $[63,64]$. The $\alpha$-secretase ADAM10 protease is also present in DCSV [58]. These findings illustrate the presence of the APP-processing machinery in the production of pGlu-A $\beta$ and $A \beta$ peptides in neurotransmitter secretory vesicles containing neuropeptides and catecholamines.

The reason for this question is that it may be hypothesized that APP and its processing secretases may be present in these secretory vesicles for the production of $A \beta$, and for the production of pGlu-A $\beta$ by QC (fig. 8). Our previous studies have shown that these secretory vesicles contain APP $[17,52,53]$ and A $\beta$ peptides, indicating the presence of secretases that convert APP to A $\beta$. Indeed, $\beta$ - and $\gamma$-secretases are present in the secretory vesicles with APP. The $\beta$-secretase BACE1 [54-57] is present in DCSV $[19,58]$. A wild-type $\beta$-secretase was recently identified as cathepsin B [59-61] and is present in DCSV $[58,59]$. The presenilin $1 \gamma$-secretase component is present in secretory vesicles $[58,62]$, as well as the nicastrin, Aph-1, and Pen-2 components [58] of the $\gamma$-secretase complex

pGlu-A $\beta$ and $\mathrm{QC}$ Colocalization with $\mathrm{A} \beta$ in Secretory Vesicles
$[63,64]$. Subsequent to the secretases, $\mathrm{N}$-terminal truncation of full-length $A \beta$ is predicted to occur in order to generate $A \beta(3-40 / 42)$, which serves as a substrate for $Q C$ to produce pGlu-A $\beta(3-40 / 42)$ [65-68]. In future studies, it will be of interest to determine the relative levels of the $\mathrm{N}$-truncated $\mathrm{A} \beta$ peptides $\mathrm{A} \beta(2-40 / 42)$ and $\mathrm{A} \beta(3-40 / 42)$ compared with pGlu-A $\beta(3-40 / 42)$, utilizing mass spectrometry to distinguish these peptide species. Thus, secretory vesicles contain the APP-processing proteases that produce $\mathrm{A} \beta$ peptides combined with $\mathrm{QC}$ for the production of pGlu-A $\beta(3-40 / 42)$ (fig. 8). The range of $\mathrm{pH}$ conditions necessary for the activities of these secretases [6974] coincides with the internal $\mathrm{pH}$ conditions of these secretory vesicles [75-77]. The secretory vesicle organelle, thus, contains the APP-processing machinery for producing $A \beta$ and $p G l u-A \beta$ peptide forms.

These data support the hypothesis that $p G l u-A \beta$ is produced by QC in secretory vesicles that release neurotransmitter components in a regulated, activity-dependent manner. QC converts the N-terminal glutamate of $\mathrm{A} \beta(3-40 / 42)$ peptides to the pyroglutamate of pGlu$\mathrm{A} \beta(3-40 / 42)$. The $\mathrm{QC}$ substrates $\mathrm{A} \beta(3-40 / 42)$ are presumably produced by $\mathrm{N}$-terminal truncation of $\mathrm{A} \beta(1-$ $40 / 42)$. The presence of full-length $A \beta(1-40 / 42)$ in secretory vesicles $[19,58,59]$ is compatible with biosynthesis of pGlu-A $\beta$ from $A \beta$ in these secretory vesicles.

The DCSV is a key organelle for the regulated, activitydependent release of peptide and catecholamine neurotransmitters. Indeed, regulated secretion of pGlu-A $\beta$ and $A \beta$ occurs with the peptide neurotransmitters Metenkephalin and galanin. Evidence for cosecretion of $A \beta$ peptides with neurotransmitters supports involvement of activity-dependent deposition of $\mathrm{A} \beta$ peptides in $\mathrm{AD}$ brains, as demonstrated in vivo [21,22]. It will be of interest in future studies to examine the variety of secretagogues known to induce neurotransmitter secretion [7883] for effects on the stimulation of the regulated secretion of $\mathrm{pGlu}-\mathrm{A} \beta$ peptides in order to gain further understanding of factors controlling pGlu- $A \beta$ release. It is noted that the DCSV isolated from the peripheral sympathetic nervous system (from adrenal medulla) contain pGlu-A $\beta$, whereas this is not detectable in normal aged human brains [84]. Thus, the DCSV utilized in this study provide a model for understanding the neurobiology of pGlu-A $\beta$.

Further, it is noted that it is not yet known whether pGlu-A $\beta$ is located in other subcellular organelles that contain full-length $A \beta(1-40 / 42)$. Full-length $A \beta$ is present in endosomes [85-89], lysosomes [90-92], autophagosomes [91, 93-95], exosomes [96, 97], and other 
related subcellular organelles. It will be important in future studies to compare the organelle locations of pGlu$A \beta$ and $A \beta$ peptides, which will provide an understanding of the neuronal trafficking of $\mathrm{pGlu}-\mathrm{A} \beta$ compared with $\mathrm{A} \beta$.

The neurobiology of the regulated, activity-dependent secretion of pGlu-A $\beta$ and $A \beta$ is significant with respect to the functional role of $p G l u-A \beta$ in neurodegeneration and memory loss in $\mathrm{AD}$. pGlu- $\mathrm{A} \beta$ comprises a major portion of the $A \beta$ species in $A D$ compared with $A \beta(1-40)$ and $A \beta(1-42)$ [5-7]. Quantification indicates the presence of pGlu-A $\beta$ peptides at similar and greater levels than $A \beta(1-$ $40)$ and $A \beta(1-42)$ in $A D$ brains. Also, pGlu- $A \beta$ is present as oligomeric complexes in $\mathrm{AD}$ brains [98]. In vitro studies have shown that $\mathrm{pGlu}-\mathrm{A} \beta$ displays a higher aggregation propensity as well as a stronger tendency to seed the aggregation of other $A \beta$ species $[8,9,99]$. Moreover, pGlu- $A \beta$ is present in $A D$ brains but not in normal aged brains [84].

In vivo studies have illustrated the neurotoxicity of pGlu-A $\beta$ in memory deficits. Overexpression of pGlu-A $\beta$ in mice correlates with $A \beta$ and behavioral deficits $[10,12]$ as well as neuronal loss and impaired long-term potentiation [100]. These studies also showed that pGlu-A $\beta$ formation is dependent on QC, since knockout of QC in transgenic mice resulted in reduced levels of brain pGlu$A \beta$. These findings support a role of pGlu-A $\beta$ in amyloid plaque formation and memory loss in $\mathrm{AD}$.

Reduction of $\mathrm{pGlu}-\mathrm{A} \beta$ formation may provide a therapeutic strategy for $A D$, since inhibition of $Q C$ results in decreased brain pGlu-A $\beta[13,14]$ and QC gene knockout decreases brain pGlu-A $\beta$ with improved behavior [12]. These findings indicate that $\mathrm{QC}$ is involved in the development of $\mathrm{AD}$ via the formation of pGlu-A $\beta$.

Based on the results of this study, inhibition of QC reduces the amount of $\mathrm{pGlu}-\mathrm{A} \beta$ released from the regulated secretory pathway. In future studies, it will be of interest to assess the effects of QC inhibition on the regulated, activity-dependent deposition of amyloid in animal AD model brains. The production of pGlu-A $\beta$ by $\mathrm{QC}$ in secretory vesicles that produce and secrete $A \beta$ peptides and neurotransmitters in an activity-dependent manner suggests a close association of pGlu-A $\beta$ and $A \beta$ neurotoxicity with neurotransmitter functions.

\section{Acknowledgements}

This study was supported by grants from the Alzheimer's Association and the National Institutes of Health to Vivian Hook, and by National Institutes of Health grants to Michael Ziegler.

\section{References}

1 Selkoe DJ: Alzheimer's disease: genes, proteins, and therapy. Physiol Rev 2001;81:741766.

2 Gandy S, Martins RN, Buxbaum J: Molecular and cellular basis for anti-amyloid therapy in Alzheimer's disease. Alzheimer Dis Assoc Disord 2003;17:259-266.

-3 Crews L, Masliah E: Molecular mechanisms of neurodegeneration in Alzheimer's disease. Hum Mol Genet 2010;19:R12-R20.

-4 Huang Y, Mucke L: Alzheimer mechanisms and therapeutic strategies. Cell 2012;16:12041222.

5 Saido TC, Iwatsubo T, Mann DM, Shimada H, Ihara Y, Kawashima S: Dominant and differential deposition of distinct $\beta$-amyloid peptide species, $A \beta_{\mathrm{N} 3(\mathrm{pE})}$, in senile plaques. Neuron 1995;14:457-466.

-6 Kuo YM, Emmerling MR, Woods AS, Cotter RJ, Roher AE: Isolation, chemical characterization, and quantitation of $\mathrm{A} \beta$ 3-pyroglutamyl peptide from neuritic plaques and vascular amyloid deposits. Biochem Biophys Res Commun 1997;237:188-191.

7 Harigaya Y, Saido TC, Eckman CB, Prada CM, Shoji M, Younkin SG: Amyloid beta protein starting pyroglutamate at position 3 is a major component of the amyloid deposits in the Alzheimer's disease brain. Biochem Biophys Res Commun 2000;276:422-427.

-8 Schilling S, Lauber T, Schaupp M, Manhart S, Scheel E, Böhm G, Demuth HU: On the seeding and oligomerization of pGlu-amyloid peptides (in vitro). Biochemistry 2006;45: 12393-12399.

-9 Nussbaum JM, Schilling S, Cynis H, Silva A, Swanson E, Wangsanut T, Tayler K, Wiltgen B, Hatami A, Rönicke R, Reymann K, HutterPaier B, Alexandru A, Jagla W, Graubner S, Glabe CG, Demuth HU, Bloom GS: Prionlike behaviour and tau-dependent cytotoxicity of pyroglutamylated amyloid- $\beta$. Nature 2012;485:651-655.

10 Wittnam JL, Portelius E, Zetterberg H, Gustavsson MK, Schilling S, Koch B, Demuth HU, Blennow K, Wirths O, Bayer TA: Pyroglutamate amyloid $\beta(\mathrm{A} \beta)$ aggravates behavioral deficits in transgenic amyloid mouse model for Alzheimer disease. J Biol Chem 2012;287:8154-8162.

11 Cynis H, Scheel E, Saido TC, Schilling S, Demuth HU: Amyloidogenic processing of amyloid precursor protein: evidence of a pivotal role of glutaminyl cyclase in generation of pyroglutamate-modified amyloid- $\beta$. Biochemistry 2008;47:7405-7413.
12 Jawhar S, Wirths O, Schilling S, Graubner S, Demuth HU, Bayer TA: Overexpression of glutaminyl cyclase, the enzyme responsible for pyroglutamate $A \beta$ formation, induces behavioral deficits, and glutaminyl cyclase knock-out rescues the behavioral phenotype in 5XFAD mice. J Biol Chem 2011;286:44544460.

13 Schilling S, Zeitschel U, Hoffmann T, Heiser U, Francke M, Kehlen A, Holzer M, HutterPaier B, Prokesch M, Windisch M, Jagla W, Schlenzig D, Lindner C, Rudolph T, Reuter G, Cynis H, Montag D, Demuth HU, Rossner S: Glutaminyl cyclase inhibition attenuates pyroglutamate $\mathrm{A} \beta$ and Alzheimer's disease-like pathology. Nat Med 2008;14:1106-1111.

14 Schilling S, Appl T, Hoffmann T, Cynis H, Schulz K, Jagla W, Friedrich D, Wermann M, Buchholz M, Heiser U, von Hörsten S, Demuth HU: Inhibition of glutaminyl cyclase prevents pGlu-A $\beta$ formation after intracortical/hippocampal microinjection in vivo/in situ. J Neurochem 2008;106:1225-1236.

15 Nitsch RM, Slack BE, Wurtman RJ, Growdon JH: Release of Alzheimer's amyloid precursor derivatives by activation of muscarinic acetylcholine receptors. Science 1992;258:304307. 
-16 Nitsch RJ, Farber SA, Growdon JH, Wurtman RJ: Release of amyloid $\beta$-protein precursor derivatives by electrical depolarization of rat hippocampal slices. Proc Natl Acad Sci USA 1993;90:5191-5193.

-17 Efthimiopoulos S, Vassilacopoulou D, Rippellino JA, Tezapsidis N, Robakis NK: Cholinergic agonists stimulate secretion of soluble full-length amyloid precursor protein in neuroendocrine cells. Proc Natl Acad Sci USA 1996;93:8046-8050.

- 18 Jolly-Tornetta C, Gao ZY, Lee VM, Wolf BA: Regulation of amyloid precursor protein secretion by glutamate receptors in human Ntera 2 neurons. J Biol Chem 1998;272: 140015-140021.

19 Hook VYH, Toneff T, Aaron W, Yasothornsrikul S, Bundey R, Reisine T: $\beta$-Amyloid peptide in regulated secretory vesicles of chromaffin cells: evidence for multiple cysteine proteolytic activities in distinct pathways for $\beta$-secretase activity in chromaffin vesicles. J Neurochem 2002;81:237-256.

-20 Kamenetz F, Tomita T, Hsieh H, Seabrok G, Borchelt D, Iwatsubo T, Sisodia S, Malinow R: APP processing and synaptic function. Neuron 2003;37:925-937.

-21 Tampellini D, Capetillo-Zarate E, Dumont M, Huang Z, Yu F, Lin MT, Gouras GK: Effects of synaptic modulation on $\beta$-amyloid, synaptophysin, and memory performance in Alzheimer's disease transgenic mice. J Neurosci 2010;30:14299-14304.

- 22 Bero AW, Yan P, Roh JE, Cirrito JR, Stewart FR, Raichle ME, Lee JM, Holtzman DM: Neuronal activity regulates the regional vulnerability to amyloid-beta deposition. Nature 2011;14:750-758.

23 Siegel GJ, Agranoff BS, Albers RW, Fisher SK, Uhler MD: Basic Neurochemistry, ed 6. Philadelphia, Lippincott-Raven, 1999, pp 191-400.

24 Squire L, Berg D, Bloom F, du Lac S, Ghosh A, Spitzer N: Fundamental Neuroscience, ed 3. Amsterdam, Elsevier, 2008, pp 41-271.

25 Wegrzyn JL, Bark SJ, Funkelstein L, Mosier CA, Yap A, Kazemi-Esfarjani P, la Spada AR, Sigurdson C, O'Connor DT, Hook V: Proteomics of dense core secretory vesicles reveal distinct protein categories for secretion of neuroeffectors for cell-cell communication. J Proteome Res 2010;9:5002-5024.

-26 Gupta N, Bark SJ, Lu WD, Taupenot L, O'Connor DT, Pevzner P, Hook V: Mass spectrometry-based neuropeptidomics of secretory vesicles from human adrenal medullary pheochromocytoma reveals novel peptide products of prohormone processing. J Proteome Res 2010;9:5065-5075.

27 Smith AD, Winkler H: A simple method for the isolation of adrenal chromaffin granules on a large scale. Biochem J 1967;103:480-482.

-28 Bark SJ, Wegrzyn J, Taupenot L, Ziegler M, O'Connor DT, Ma Q, Smoot M, Ideker T, Hook V: The protein architecture of human secretory vesicles reveals differential regulation of signaling molecule secretion by protein kinases. PLoS One 2012;7:e41134.
29 Hook VH, Eiden LE: Two peptidases that convert ${ }^{125}$ I-Lys-Arg(Met)enkephalin and ${ }^{125} \mathrm{I}$-(Met)enkephalin-Arg ${ }^{6}$, respectively, to ${ }^{125} \mathrm{I}$-(Met)enkephalin in bovine adrenal medullary chromaffin granules. FEBS Lett 1984; 172:212-218.

30 Schilling S, Hoffmann T, Wermann M, Heiser U, Wasternack C, Demuth HU: Continuous spectrometric assays for glutaminyl cyclase activity. Anal Biochem 2002;303:49-56.

-31 Schilling S, Cynis H, von Bohlen A, Hoffmann T, Wermann M, Heiser U, Buchholz M, Zunkel K, Demuth HU: Isolation, catalytic properties, and competitive inhibitors of the zincdependent murine glutaminyl cyclase. Biochemistry 2005;44:13415-13424.

- 32 Stephan A, Wermann M, von Bohlen A, Koch B, Cynis H, Demuth HU, Schilling S: Mammalian glutaminyl cyclases and their isoenzymes have identical enzymatic characteristics. FEBS J 2009;276:6522-6536.

33 Funkelstein L, Lu WD, Koch B, Mosier C, Toneff T, Taupenot L, O'Connor DT, Reinheckel T, Peters C, Hook V: Human cathepsin $\mathrm{V}$ protease participates in production of enkephalin and NPY neuropeptide neurotransmitters. J Biol Chem 2012;287:15232-15241.

34 Minokadeh A, Funkelstein L, Toneff T, Hwang SR, Beinfeld M, Reinheckel T, Peters C, Zadina J, Hook V: Cathepsin L participates in dynorphin production in brain cortex, illustrated by protease gene knockout and expression. Mol Cell Neurosci 2010;43:98-107.

35 Yasothornsrikul S, Greenbaum D, Medzihradszky KF, Toneff T, Bundey R, Miller R, Schilling B, Petermann I, Dehnert J, Logvinova A, Goldsmith P, Neveu JM, Lane WS, Gibson B, Reinheckel T, Peters C, Bogyo M, Hook V: Cathep$\sin \mathrm{L}$ in secretory vesicles functions as a prohormone-processing enzyme for production of the enkephalin peptide neurotransmitter. Proc Natl Acad Sci USA 2003;100:9590-9595.

-36 Ziegler MG, Kennedy B, Elayan H: A sensitive radioenzymatic assay for epinephrine forming enzymes. Life Sci 1988;43:2117-2122.

37 Vaingankar SM, Li Y, Biswas N, Gayen J, Choksi S, Rao F, Ziegler MG, Mahata SK, O'Connor DT: Effects of chromogranin A deficiency and excess in vivo: biphasic blood pressure and catecholamine responses. J Hypertens 2010;28:817-825.

38 O'Connor DT, Mahata SK, Mahata M, Jiang Q, Hook VY, Taupenot L: Primary culture of bovine chromaffin cells. Nat Protoc 2007;2: 1248-1253.

39 Funkelstein L, Toneff T, Mosier C, Hwang SR, Beuschlein F, Lichtenauer UD, Reinheckel T, Peters C, Hook V: Major role of cathepsin L for producing the peptide hormones $\mathrm{ACTH}$, $\beta$-endorphin, and $\alpha$-MSH, illustrated by protease gene knockout and expression. J Biol Chem 2008;283:35652-35659.

40 Hwang SR, Garza C, Mosier C, Toneff T, Wunderlich E, Goldsmith P, Hook V: Cathepsin L expression is directed to secretory vesicles for enkephalin neuropeptide biosynthesis and secretion. J Biol Chem 2007;282:9556-9563.
41 Mahata SK, Mahata M, Wen G, Wong WB, Mahapatra NR, Hamilton BA, O'Connor DT: The catecholamine release-inhibitory 'catestatin' fragment of chromogranin A: naturally occurring human variants with different potencies for multiple chromaffin cell nicotinic cholinergic responses. Mol Pharmacol 2004;66:1180-1191.

42 Sala F, Nistri A, Criado M: Nicotinic acetylcholine receptors of adrenal chromaffin cells. Acta Physiol 2008;192:203-212.

43 Cirrito JR, Yamada KA, Finn MB, Sloviter RS, Bales KR, May PC, Schoepp DD, Paul SM, Mennerick S, Holtzman DM: Synaptic activity regulates interstitial fluid amyloid-beta levels in vivo. Neuron 2005;48:913-922.

44 Das U, Scott DA, Ganguly A, Koo EH, Tang Y, Roy S: Activity-induced convergence of APP and BACE-1 in acidic microdomains via an endocytosis-dependent pathway. Neuron 2013;79:447-460.

45 Kim SH, Fraser PE, Westaway D, St GeorgeHyslop PH, Ehrlich ME, Gandy S: Group II metabotropic glutamate receptor stimulation triggers production and release of Alzheimer's amyloid $\beta_{42}$ from isolated intact nerve terminals. J Neurosci 2010;30:3870-3875.

46 Lundblad M, Decressac M, Mattsson B, Björklund A: Impaired neurotransmission caused by overexpression of $\alpha$-synuclein in nigral dopamine neurons. Proc Natl Acad Sci USA 2012;109:3213-3219.

47 Yang L, Zhao L, Gan Z, He Z, Xu J, Gao X, Wang X, Han W, Chen L, Xu T, Li W, Liu Y: Deficiency in RNA editing enzyme ADAR2 impairs regulated exocytosis. FASEB J 2010; 24:3720-3732.

48 Hwang SR, Steineckert B, Yasothornsrikul S, Sei CA, Toneff T, Rattan J, Hook VY: Molecular cloning of endopin 1 , a novel serpin localized to neurosecretory vesicles of chromaffin cells: inhibition of basic residue-cleaving proteases by endopin 1. J Biol Chem 1999;274: 34164-34173.

49 Taylor CV, Taupenot L, Mahata SK, Mahata $\mathrm{M}, \mathrm{Wu} \mathrm{H}$, Yasothornsrikul S, Toneff T, Caporale C, Jiang Q, Parmer RJ, Hook VY, O'Connor DT: Formation of the catecholamine release-inhibitory peptide catestatin from chromogranin A: determination of proteolytic cleavage sites in hormone storage granules. J Biol Chem 2000;275:22905-22915.

50 Todd RD, McDavid SM, Brindley RL, Jewell ML, Currie KP: Gabapentin inhibits catecholamine release from adrenal chromaffin cells. Anesthesiology 2012;116:1013-1024.

51 Cynis H, Hoffmann T, Friedrich D, Kehlen A, Gans K, Kleinschmidt M, Rahfeld JU, Wolf R, Wermann M, Stephan A, Haegele M, Sedlmeier R, Graubner S, Jagla W, Müller A, Eichentopf R, Heiser U, Seifert F, Quax PH, de Vries MR, Hesse I, Trautwein D, Wollert U, Berg S, Freyse EJ, Schilling S, Demuth HU: The isoenzyme of glutaminyl cyclase is an important regulator of monocyte infiltration under inflammatory conditions. EMBO Mol Med 2011;3:545-558. 
52 Vassilacopoulou D, Ripellino JA, Tezapsidis N, Hook VYH, Robakis NK: Full-length and truncated Alzheimer amyloid precursors in chromaffin granules: solubilization of membrane amyloid precursor is mediated by an enzymatic mechanism. J Neurochem 1995;64: 2140-2146.

53 Tezapsidis N, Li HC, Ripellino JA, Efthimiopoulos S, Vassilacopoulou D, Sambamurti K, Toneff T, Yasothornsrikul S, Hook VYH, Robakis NK: Release of nontransmembrane fulllength Alzheimer's amyloid precursor protein from the lumenar surface of chromaffin granule membranes. Biochemistry 1998;37:12741282.

54 Crews L, Masliah E: Molecular mechanisms of neurodegeneration in Alzheimer's disease. Hum Mol Genet 2010;19:R12-R20.

55 Huang Y, Mucke L: Alzheimer mechanisms and therapeutic strategies. Cell 2012;16:12041222.

56 Vassar R, Kovacs DM, Uan R, Wong PC: The $\beta$-secretase enzyme BACE in health and Alzheimer's disease: regulation, cell biology, function, and therapeutic potential. J Neurosci 2009;29:12787-12794.

57 Kandelepas PC, Vassar R: Identification and biology of $\beta$-secretase. J Neurochem 2012;1: 55-61.

58 Toneff T, Funkelstein L, Mosier C, Ziegler M, Hook V: $\beta$-Amyloid peptides undergo regulated secretion with peptide and catecholamine neurotransmitters from dense core secretory vesicles. Peptides 2013;46:125-135.

-59 Hook V, Toneff T, Bogyo M, Greenbaum D, Medzihradszky KF, Neveu J, Lane W, Hook G, Reisine T: Inhibition of cathepsin B reduces $\beta$-amyloid production in regulated secretory vesicles of neuronal chromaffin cells: evidence for cathepsin B as a candidate $\beta$-secretase of Alzheimer's disease. Biol Chem 2005;386:931-940.

60 Hook VY, Kindy M, Hook G: Inhibitors of cathepsin B improve memory and reduce $\beta$-amyloid in transgenic Alzheimer disease mice expressing the wild-type, but not the Swedish mutant, $\beta$-secretase site of the amyloid precursor protein. J Biol Chem 2008;283: 7745-7753.

61 Kindy M, Yu J, Zhu H, El-Amouri SS, Hook V, Hook GR: Deletion of the cathepsin B gene improves memory deficits in a transgenic Alzheimer's disease mouse model expressing APP containing the wild-type $\beta$-secretase site sequence. J Alzheimers Dis 2012;29:827-840.

-62 Efthimiopoulos S, Floor E, Georgakopoulos A, Shioi J, Cui W, Yasothornsrikul S, Hook VY, Wisniewski T, Buee L, Robakis NK: Enrichment of presenilin 1 peptides in neuronal large dense-core and somatodendritic clathrin-coated vesicles. J Neurochem 1998;71: 2365-2372.

-63 Kimberly WT, LaVoie MJ, Ostaszewski BL, Ye W, Wolfe MS, Selkoe DJ: $\gamma$-Secretase is a membrane protein complex comprised of presenilin, nicastrin, Aph-1, and Pen-2. Proc Natl Acad Sci USA 2003;100:6382-6387.
64 Lee SF, Shah S, Li H, Yu C, Han W, Yu G: Mammalian APH-1 interacts with presenilin and nicastrin and is required for intramembrane proteolysis of amyloid- $\beta$ precursor protein and Notch. J Biol Chem 2002;277:4501345019.

-65 Portelius E, Bogdanovic N, Gustavsson MK, Volkmann I, Brinkmalm G, Zetterberg $\mathrm{H}$, Winblad B, Blennow K: Mass spectrometric characterization of brain amyloid beta isoform signatures in familial and sporadic Alzheimer's disease. Acta Neuropathol 2010;120: 185-193.

66 Nutu M, Bourgeois P, Zetterberg H, Portelius E, Andreasson U, Parent S, Lipari F, Hall S, Constantinescu R, Hansson O, Blennow K: $A \beta_{1-15 / 16}$ as a potential diagnostic marker in neurodegenerative diseases. Neuromolecular Med 2013;15:169-179.

67 Portelius E, Brinkmalm G, Tran A, Andreasson $\mathrm{U}$, Zetterberg $\mathrm{H}$, Westman-Brinkmalm A, Blennow K, Ohrfelt A: Identification of novel N-terminal fragments of amyloid precursor protein in cerebrospinal fluid. Exp Neurol 2010;223:351-358.

68 Leissring MA: The A $\beta C$ s of $A \beta$-cleaving proteases. J Biol Chem 2008;283:29645-29659.

69 Ermolieff J, Loy JA, Koelsch G, Tang J: Proteolytic activation of recombinant pro-memapsin 2 (Pro- $\beta$-secretase) studied with new fluorogenic substrates. Biochemistry 2000;39: 16263.

70 Lin X, Koelsch G, Wu S, Downs D, Dashti A, Tang J: Human aspartic protease memapsin 2 cleaves the $\beta$-secretase site of $\beta$-amyloid precursor protein. Proc Natl Acad Sci USA 2000; 97:1456-1460.

71 Vassar R, Bennett BD, Babu-Khan S, Kahn S, Mendiaz EA, Denis P, Teplow DB, Ross S, Amarante P, Loeloff R, Luo Y, Fisher S, Fuller J, Edenson S, Lile J, Jarosinski MA, Biere AL, Curran E, Burgess T, Louis JC, Collins F, Treanor J, Rogers G, Citron M: $\beta$-Secretase cleavage of Alzheimer's amyloid precursor protein by the transmembrane aspartic protease BACE. Science 1999;286:735-741.

72 Quintero-Monzon O, Martin MM, Fernandez MA, Cappello CA, Krzysiak AJ, Osenkowski P, Wolfe MS: Dissociation between the processivity and total activity of $\gamma$-secretase: implications for the mechanism of Alzheimer's disease-causing presenilin mutations. Biochemistry 2011;50:9023-9035.

73 Li YM, Lai MT, Xu M, Huang Q, DiMuzioMower J, Sardana MK, Shi XP, Yin KC, Shafer JA, Gardell SJ: Presenilin 1 is linked with $\gamma$-secretase activity in the detergent solubilized state. Proc Natl Acad Sci USA 2000;97: 6138-6143.

74 Fraering PC, Ye W, Strub JM, Dolios G, LaVoie MJ, Ostaszewski BL, van Dorsselaer A, Wang R, Selkoe DJ, Wolfe MS: Purification and characterization of the human $\gamma$-secretase complex. Biochemistry 2004;43:9774-9789.
75 Hook V, Funkelstein L, Lu D, Bark S, Wegrzyn J, Hwang SR: Proteases for processing proneuropeptides into peptide neurotransmitters and hormones. Annu Rev Pharmacol Toxicol 2008;48:393-423.

76 Loh YP, Tam WW, Russell JT: Measurement of $\Delta \mathrm{pH}$ and membrane potential in secretory vesicles isolated from bovine pituitary intermediate lobe. J Biol Chem 1984;259:8238-8245.

77 Pollard HB, Shindo H, Creutz CE, Pazoles CJ, Cohen JS: Internal $\mathrm{pH}$ and state of ATP in adrenergic chromaffin granules determined by ${ }^{31} \mathrm{P}$ nuclear magnetic resonance spectroscopy. J Biol Chem 1979;254:1170-1177.

78 Parmer RJ, Mahata M, Mahata S, Sebald MT, O'Connor DT, Miles LA: Tissue plasminogen activator (t-PA) is targeted to the regulated secretory pathway: catecholamine storage vesicles as a reservoir for the rapid release of t-PA. J Biol Chem 1997;272:1976-1982.

79 Bark SJ, Wegrzyn J, Taupenot L, Ziegler M, O'Connor D, Ma Q, Smoot M, Ideker T, Hook $\mathrm{V}$ : The protein architecture of human secretory vesicles reveals differential regulation of signaling molecule secretion by protein kinases. PloS One 2012;7:e41134.

80 Cox ME, Parsons SJ: Roles for protein kinase $\mathrm{C}$ and mitogen-activated protein kinase in nicotine-induced secretion from bovine adrenal chromaffin cells. J Neurochem 1997;69: 1119-1130.

81 Vitale N, Mukai H, Rouot B, Thiersé D, Aunis D, Bader MF: Exocytosis in chromaffin cells: possible involvement of the heterotrimeric GTP-binding protein $\mathrm{G}_{\mathrm{o}}$. J Biol Chem 1993; 268:14715-14723.

82 Simon JP, Bader MF, Aunis D: Effect of secretagogues on chromogranin A synthesis in bovine cultured chromaffin cells: possible regulation by protein kinase C. Biochem J 1989; 260:915-922.

83 Bommer M, Herz A: Neuropeptides and other secretagogues in bovine chromaffin cells: their effect on opioid peptide metabolism. Neuropeptides 1989;13:243-251.

84 Piccini A, Russo C, Gliozzi A, Relini A, Vitali A, Borghi R, Giliberto L, Armirotti A, D’Arrigo C, Markesbery W, Gambetti P, Tabaton $\mathrm{M}$ : $\beta$-Amyloid is different in normal aging and in Alzheimer disease. J Biol Chem 2005;280:34186-34192.

85 Ginsberg SD, Mufson EJ, Counts SE, Wuu J, Alldred MJ, Nixon RA, Che S: Regional selectivity of rab5 and rab7 protein upregulation in mild cognitive impairment and Alzheimer's disease. J Alzheimers Dis 2010;22:631-639.

86 Grbovic OM, Mathews PM, Jiang Y, Schmidt SD, Dinakar R, Summers-Terio NB, Ceresa BP, Nixon RA, Cataldo AM: Rab5-stimulated up-regulation of the endocytic pathway increases intracellular $\beta$-cleaved amyloid precursor protein carboxyl-terminal fragment levels and $\mathrm{A} \beta$ production. J Biol Chem 2003; 278:31261-31268. 
87 Jiang Y, Mullaney KA, Peterhoff CM, Che S, Schmidt SD, Boyer-Boiteau A, Ginsberg SD, Cataldo AM, Mathews PM, Nixon RA: Alzheimer's-related endosome dysfunction in Down syndrome is $A \beta$-independent but requires APP and is reversed by BACE-1 inhibition. Proc Natl Acad Sci USA 2010;107:16301635.

88 Koo EH, Squazzo SL: Evidence that production and release of amyloid $\beta$-protein involves the endocytic pathway. J Biol Chem 1994;269: 17386-17389.

89 Lee J, Retamal C, Cuitiño L, Caruano-Yzermans A, Shin JE, van Kerkhof P, Marzolo MP, $\mathrm{Bu} \mathrm{G}$ : Adaptor protein sorting nexin 17 regulates amyloid precursor protein trafficking and processing in the early endosomes. J Biol Chem 2008;283:11501-11508.

90 Lee S, Sato Y, Nixon RA: Lysosomal proteolysis inhibition selectively disrupts axonal transport of degradative organelles and causes an Alzheimer's-like axonal dystrophy. J Neurosci 2011;31:7817-7830.

-91 Lee JH, Yu WH, Kumar A, Lee S, Mohan PS, Peterhoff CM, Wolfe DM, Martinez-Vicente M, Massey AC, Sovak G, Uchiyama Y, Westaway D, Cuervo AM, Nixon RA: Lysosomal proteolysis and autophagy require presenilin 1 and are disrupted by Alzheimer-related PS1 mutations. Cell 2010;141:1146-1158.

\$2 Mathews PM, Guerra CB, Jiang Y, Grbovic OM, Kao BH, Schmidt SD, Dinakar R, Mercken M, Hille-Rehfeld A, Rohrer J, Mehta P, Cataldo AM, Nixon RA: Alzheimer's diseaserelated overexpression of the cation-dependent mannose 6-phosphate receptor increases $\mathrm{A} \beta$ secretion: role for altered lysosomal hydrolase distribution in $\beta$-amyloidogenesis. J Biol Chem 2002;277:5299-5307.
3 Nixon RA: The role of autophagy in neurodegenerative disease. Nat Med 2013;19:983-997.

94 Nixon RA, Yang DS: Autophagy failure in Alzheimer's disease: locating the primary defect. Neurobiol Dis 2011;43:38-45.

95 Yang DS, Stavrides P, Mohan PS, Kaushik S, Kumar A, Ohno M, Schmidt SD, Wesson D, Bandyopadhyay U, Jiang Y, Pawlik M, Peterhoff CM, Yang AJ, Wilson DA, St GeorgeHyslop P, Westaway D, Mathews PM, Levy E, Cuervo AM, Nixon RA: Reversal of autophagy dysfunction in the TgCRND8 mouse model of Alzheimer's disease ameliorates amyloid pathologies and memory deficits. Brain 2011; 134:258-277.

96 Perez-Gonzalez R, Gauthier SA, Kumar A, Levy E: The exosome secretory pathway transports amyloid precursor protein carboxyl-terminal fragments from the cell into the brain extracellular space. J Biol Chem 2012; 287:43108-43115.

97 Rajendran L, Honsho M, Zahn TR, Keller P, Geiger KD, Verkade P, Simons K: Alzheimer's disease $\beta$-amyloid peptides are released in association with exosomes. Proc Natl Acad Sci USA 2006;103:11172-11177.

98 Wirths O, Erck C, Martens H, Harmeier A, Geumann C, Jawhar S, Kumar S, Multhaup G, Walter J, Ingelsson M, Degerman-Gunnarsson M, Kalimo H, Huitinga I, Lannfelt L, Bayer TA: Identification of low molecular weight pyroglutamate $A \beta$ oligomers in Alzheimer disease: a novel tool for therapy and diagnosis. J Biol Chem 2010;285:41517-41524.
99 Schlenzig D, Manhart S, Cinar Y, Kleinschmidt M, Hause G, Willbold D, Funke SA, Schilling S, Demuth HU: Pyroglutamate formation influences solubility and amyloidogenicity of amyloid peptides. Biochemistry 2009;48:7072-7078.

100 Alexandru A, Jagla W, Graubner S, Becker A, Bäuscher C, Kohlmann S, Sedlmeier R, Raber KA, Cynis H, Rönicke R, Reymann KG, Petrasch-Parwez E, Hartlage-Rübsamen M, Waniek A, Rossner S, Schilling S, Osmand AP, Demuth HU, von Hörsten S: Selective hippocampal neurodegeneration in transgenic mice expressing small amounts of truncated $\mathrm{A} \beta$ is induced by pyroglutamateA $\beta$ formation. J Neurosci 2011;31:1279012801.

101 Fischer WH, Spiess J: Identification of a mammalian glutaminyl cyclase converting glutaminyl into pyroglutamyl peptides. Proc Natl Acad Sci 1987;84:3628-3632.

102 Booth RE, Misquitta SA, Bateman RC Jr: Human pituitary glutaminyl cyclase: expression in insect cells and dye affinity purification. Protein Expr Purif 2003;32:141-146.

103 Matsuoka Y, Saito M, LaFrancois J, Saito M, Gaynor K, Olm V, Wang L, Casey E, Lu Y, Shiratori C, Lemere C, Duff K: Novel therapeutic approach for the treatment of Alzheimer's disease by peripheral administration of agents with an affinity to $\beta$-amyloid. J Neurosci 2003;23:29-33.

104 Roberson ED, Scearce-Levie K, Palop JJ, Yan F, Cheng IH, Wu T, Gerstein H, Yu GQ Mucke L: Reducing endogenous tau ameliorates amyloid $\beta$-induced deficits in an Alzheimer's disease mouse model. Science 2007;316:750-754. 